\title{
Increased Activeness and Cognitive Learning Outcomes of Students Through Problem Based Learning Models
}

\author{
Novela Ayu Permatasari \\ Universitas Sebelas Maret \\ novelaayu19@gmail.com
}

\section{Article History}

received 30/4/2021

\begin{abstract}
The background of this research is the low activity and learning outcomes of students. The purpose of this study was to increase the activeness and cognitive learning outcomes of students in the content of Mathematics lessons about object weight measurement through the PBL model for class IIA students at SD Negeri 04 Jaten. This Classroom Action Research was conducted in two cycles. The research subjects were students of class IIA SDN 04 Jaten. The activeness of students from pre-cycle activities to cycle 2 activities increased by $60.75 \%$ from the less active category to very active. Meanwhile, the learning outcomes of students in precycle activities were only $23.73 \%$ who completed to $95.65 \%$ who completed. The conclusions that can be drawn are based on the research that has been carried out, namely the application of the PBL model can increase the activeness and cognitive learning outcomes of class IIA students at SDN 04 Jaten.
\end{abstract}

Keywords: Activeness, Learning Outcomes, Mathematics, Problem Based Learning

\begin{abstract}
Abstrak
Latar belakang penelitian ini adalah rendahnya keaktifan dan hasil belajar peserta didik. Tujuan penelitian ini adalah untuk meningkatkan keaktifan dan hasil belajar kognitif siswa pada materi muatan pelajaran Matematika tentang pengukuran berat benda melalui model PBL pada siswa kelas IIA di SD Negeri 04 Jaten. Penelitian Tindakan Kelas ini dilaksanakan dalam dua siklus. Subjek penelitian ini adalah siswa kelas IIA SDN 04 Jaten. Keaktifan siswa dari kegiatan pra siklus ke kegiatan siklus 2 meningkat sebesar $60,75 \%$ dari kategori kurang aktif menjadi sangat aktif. Sedangkan hasil belajar siswa pada kegiatan pra siklus hanya $23,73 \%$ yang tuntas hingga $95,65 \%$ yang tuntas. Kesimpulan yang dapat diambil berdasarkan penelitian yang telah dilakukan yaitu penerapan model PBL dapat meningkatkan keaktifan dan hasil belajar kognitif siswa kelas IIA di SDN 04 Jaten.
\end{abstract}

Kata kunci: Keaktifan, Hasil Belajar, Matematika, Pembelajaran Berbasis Masalah 


\section{PENDAHULUAN}

Menurut Russeffendi (1988:148) dalam Siagian (2016: 59), Matematika berasal dari bahasa Latin yaitu Mathematika yang awalnya berasal dari bahasa Yunani yaitu mathematike yang berarti mempelajari. Kata mathematike mempunyai asal katanya mathema yang berarti pengetahuan atau ilmu (knowledge, science). Kata mathematike berhubungan juga dengan kata lain yang hampir sama, yaitu mathein atau mathenein yang artinya belajar (berpikir). Jadi secara etimologis, Matematika berarti ilmu pengetahuan yang diperoleh dengan berpikir (bernalar). Sedangkan menurut Sabah (2013: 1) dalam Eismawati (2019: 72), mempelajari Matematika dimulai dari konsep yang sederhana menuju konsep yang lebih tinggi sesuai dengan perkembangan berpikir peserta didik. Sebab karakteristik matematika yaitu memiliki objek kajian yang abstrak. Pembelajaran matematika merupakan proses kegiatan belajar yang melatih peserta didik menggunakan kemampuan-kemampuan yang dimiliki untuk menyelesaikan masalah. Pembelajaran matematika di sekolah dasar menekankan pada aspek pembentukan logika, sikap, dan ketrampilan.

Proses pembelajaran matematika berpengaruh terhadap hasil belajar peserta didik. Menurut Oktaviana dan Prihatin (2018: 82), Bloom mengklasifikasikan tiga ranah hasil belajar yaitu ranah kognitif, afektif, dan psikomotor. Menurut Nurhidayati (2013: 112), ranah afektif berhubungan dengan sikap dan minat seorang peserta didik terhadapat suatu muatan pelajaran. Ranah kognitif berhubungan dengan proses berpikir. Taksonomi bloom menguraikan enam tingkat respon dalam proses berpikir yaitu: (1) pengetahuan (knowledge), (2) pemahaman (comprehension), (3) penerapan (application) (4) Analisis (analysis), (5) sintesis (synthesis), (6) penilaian (evaluation). Taksonomi Bloom tersebut kemudian dilakukan revisi oleh Anderson menjadi (1) mengingat, (2) memahami, (3) mengaplikasikan, (4) menganalisis, (5) mengevaluasi, (6) mencipta. Putri (2019) mengatakan bahwa negara-negara maju pencetus PISA telah menerapkan taksonomi bloom dalam sistem pendidikan mereka. Pada tahun 2018 skor PISA negara Indonesia pada kategori matematika masih rendah yaitu pada peringkat 73 dengan skor rata-rata skor 379 .

Berdasarkan observasi dan wawancara, peserta didik kelas IIA di SD N 04 Jaten memiliki kesadaran yang rendah untuk mengikuti proses pembelajaran matematika secara aktif. Kegiatan diskusi dan tanya jawab pada proses pembelajaran matematika juga belum berjalan secara menyenangkan. Hanya 20 persen peserta didik yang aktif saat berdiskusi. Peserta didik menganggap matematika merupakan materi pelajaran yang sulit. Hal ini dibuktikan dengan rendahnya nilai matematika peserta didik kelas IIA khususnya pada materi menentukan dan membandingkan berat benda. Peserta didik yang tidak tuntas KKM lebih dari setengah dari jumlah keseluruhan peserta didik di kelas IIA.

Guru saat melakukan proses mengajar belum menggunakan model pembelajaran yang jelas. Penanaman konsep materi pada buku tematik kurikulum 2013 juga belum dilakukan secara mendalam. Guru belum mengaitkan materi dengan permasalahan sehari-hari di dunia nyata dan belum menggunakan pertanyaanpertanyaan pemantik yang membutuhkan terampilan berpikir tingkat tinggi. Proses pembelajaran yang selama ini dilaksanakan cenderung mengarah pada penguasaan hafalan konsep dan teori yang bersifat abstrak. Konsep yang masih abstrak membuat peserta didik belajar tanpa memahami makna atau isinya sehingga peserta didik cepat lupa.

Proses pembelajaran matematika yang seharusnya berlangsung secara menyenangkan dan melibatkan peserta didik secara aktif tidak dapat terwujud apabila tidak segera dilakukan tindakan. Apabila tidak segera dilakukan perubahan maka akan berdampak pada kehidupan peserta didik di dunia nyata. Guru harus mampu bertanggung jawab atas semua hal yang terjadi pada kelasnya. 
Guru dituntut untuk menciptakan proses pembelajaran yang inovatif dan menyenangkan sehingga membuat peserta didik tertarik dan termotivasi dalam mengikuti pembelajaran. Pemilihan model pembelajaran yang tepat juga akan berpengaruh terhadap ketercapaian pemahaman peserta didik. Proses pembelajaran juga harus dapat mengembangkan kemampuan pemecahan masalah peserta didik dalam kehidupan sehari-hari. Maka dari itu, peneliti membuat penelitian dengan judul "Peningkatan Keaktifan dan Hasil Belajar Kognitif Peserta Didik Melalui Model Pembelajaran Problem Based Learning."

\section{METODE}

Jenis dan desain penelitian ini adalah penelitian tindakan kelas. Subjek penelitian ini yaitu peserta didik kelas IIA SDN 04 Jaten. Penelitian ini mengambil lokasi di SDN 04 Jaten, Kecamatan Jaten, Kabupaten Karanganyar. Penelitian ini dilakukan selama 6 bulan yaitu dari bulan Februari sampai bulan Juli. Teknik pengumpulan data yang digunakan dalam penelitian ini adalah observasi dan tes. Instrumen pengumpul data berupa lembar pengamatan dan kisi-kisi soal. Dalam penelitian ini peneliti menggunakan teknik pemeriksaan keabsahan data triangulasi dengan sumber dan triangulasi dengan metode. Menurut Patton dalam buku Moleong (2012: 330) triangulasi dengan sumber berarti "membandingkan dan mengecek balik derajat kepercayaan suatu informasi yang diperoleh melalui beberapa sumber. Sedangkan triangulasi dengan metode menurut Patton dalam buku Moleong (2012: 330) terdapat dua strategi, yaitu pengecekan derajat kepercayaan penemuan hasil penelitian beberapa teknik pengumpulan data dan pengecekan derajat kepercayaan beberapa sumber data dengan teknik yang berbeda. Analisis data dalam penelitian ini menggunakan model analisis deskriptif komparatof dan analisis model interaktif. Prosedur dalam penelitian ini menggunakan Penelitian Tindakan Kelas (PTK) yang terdiri dari empat tahapan dalam setiap siklus. Menurut Kurt Lewin dalam Suchaimiyah dan Latifah (2016: 23), setiap siklus terdapat tahapan, yaitu: perencanaan tindakan (planning), pelaksanaan tindakan (acting), observasi (observating), refleksi (reflecting).

\section{HASIL DAN PEMBAHASAN}

Penelitian tindakan kelas ini dilaksanakan sebanyak dua siklus dan tiap siklusnya dilaksanakan sebanyak dua pertemuan. Tahapan-tahapan yang dilaksanakan pada tiap siklus meliputi perencanan, pelaksanaan, pengamatan, dan refleksi. Pelaksanaan Tindakan dilakukan sesuai dengan perencanaan tindakan yang telah disusun. Proses pembelajaran dilaksanakan sesuai dengan rencana pelaksanaan pembelajaran (RPP) yang telah disusun. Siklus 1 dilaksanakan sebanyak 2 pertemuan. Pertemuan pertama pada tanggal 26 Februari 2021 dan pertemuan kedua pada tanggal 17 Maret 2021. Masing-masing pertemuan dilaksanakan selama $6 \times 35$ menit. Siklus 1 pertemuan pertemuan pertama fokus pada tema 6 subtema 2 pembelajaran 6 dan pertemuan kedua fokus pada tema 6 subtema 3 pembelajaran 1. Fokus penelitian ini adalah pada muatan pelajaran matematika khususnya materi menentukan dan membandingkan berat benda. Pembelajaran dilaksanakan secara tematik agar penelitian berjalan secara alami.

Hasil belajar kognitif peserta didik pada siklus 1 pertemuan 1 masih rendah. Rendahnya hasil belajar dibuktikan dengan hanya 6 peserta didik dari 23 peserta didik yang telah mencapai kriteria ketuntasan minimal. Dari hasil penelitian pada siklus 1 pertemuan 1 dan pertemuan 2 keaktifan peserta didik dan hasil belajar kognitif peserta masih kurang. Kurangnya keaktifan peserta didik dan hasil belajar kognitif peserta didik tersebut dapat disebabkan oleh beberapa faktor. Penggunaan aplikasi google meet yang masih baru membuat peserta didik perlu penyesuaian dalam proses pembelajaran. Solusi dari kendala tersebut adalah guru perlu membiasakan peserta didik menggunakan aplikasi google meet. Sintaks PBL yaitu mengorganisasikan 
peserta didik juga belum terlaksana dengan baik dikarenakan masih banyak peserta didik yang belum memiliki kesiapan secara fisik dan mental. Peserta didik juga masih banyak yang belum mencatat materi yang disampaikan oleh guru. Namun pada siklus 2 sintaks PBL mengorganisasikan peserta didik sudah terlaksana dengan baik.

Siklus 2 dilaksanakan sebanyak 2 pertemuan. Pertemuan pertama pada tanggal 1 April 2021 dan pertemuan kedua pada tanggal 7 April 2021. Masing-masing pertemuan dilaksanakan selama $6 \times 35$ menit. Siklus 2 pertemuan pertama fokus pada tema 6 subtema 4 pembelajaran 1 dan pertemuan kedua fokus pada tema 6 subtema 4 pembelajaran 4. Keaktifan peserta didik pada siklus 2 pertemuan 1 sudah dalam kategori baik. Hal ini dibuktikan dengan sudah $75 \%$ peserta didik yang berani mengemukakan pendapat pada proses diskusi.

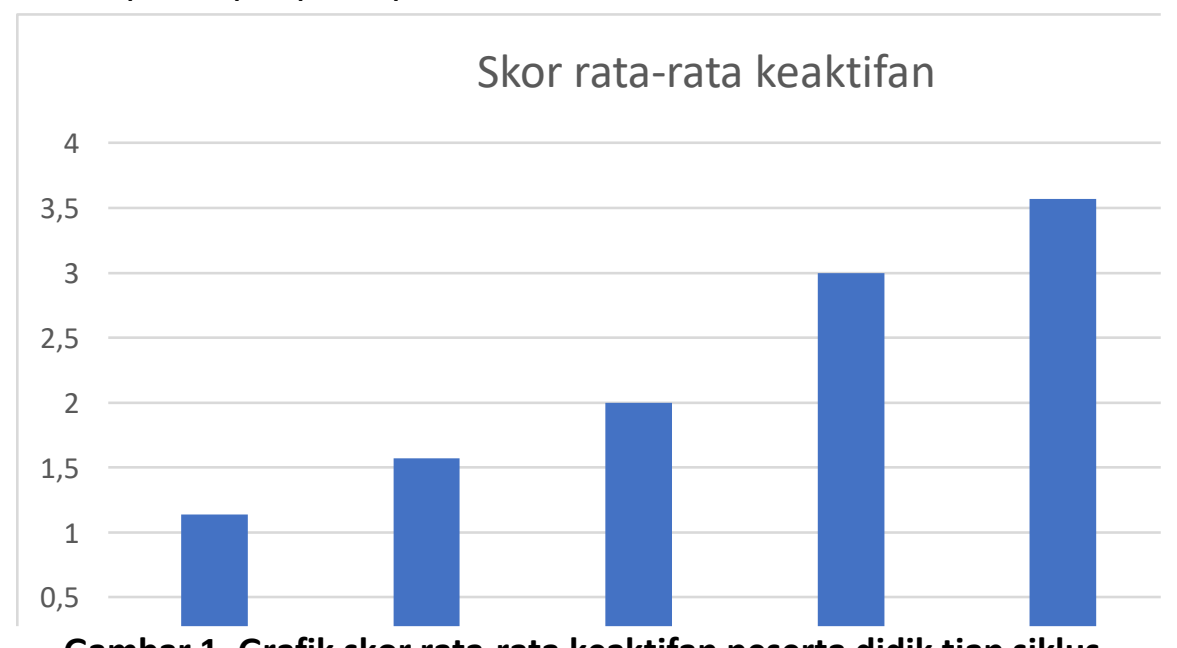

Gambar 1. Grafik skor rata-rata keaktifan peserta didik tiap siklus

Pada saat penelitian prasiklus menunjukkan bahwa peserta didik belum aktif saat proses pembelajaran dan juga hasil belajar kognitif Matematika peserta didik rendah. Hal tersebut disebabkan karena beberapa faktor salah satunya adalah model pembelajaran yang diterapkan guru belum mampu mengembangkan kemampuan berpikir secara kritis peserta didik. Peningkatan keaktifan dan hasil belajar peserta didik menjadi tujuan dari penelitian yang telah dilaksanakan. Solusi dalam penelitian yang telah dilaksanaan yaitu dengan penerapan model pembelajaran Problem Based Learning (PBL). Berdasarkan penyajian data pratindakan, deskripsi pelaksanaan siklus 1 dan siklus 2, serta perbandingan hasil tindakan menunjukkan bahwa penerapan model pembelajaran Problem Based Learning (PBL) dapat meningkatkan keaktifan dan hasil belajar peserta didik pada peserta didik kelas IIA SD Negeri 04 Jaten tahun ajaran 2020/2021. Hal tersebut dapat terlihat dari peningkatan persentase target antarsiklus. Peningkatan tersebut dapat dilihat dari kenaikan persentase ketercapaian target secara klasikal dari pratindakan, siklus 1 yang terdiri dari pertemuan 1 dan pertemuan 2 dan juga pada siklus 2 yang terdiri dari pertemuan 1 dan pertemuan 2.

Hasil belajar kognitif peserta didik pada siklus 2 pertemuan 1 sudah 21 dari 23 peserta didik yang tuntas. Sebanyak $91 \%$ peserta didik sudah mencapai kriteria ketuntasan minimal. Nilai tertinggi dan nilai terendah pada siklus 2 pertemuan 1 ini adalah 100 dan 60. Pada siklus 1 pertemuan 1 sampai silkus 2 pertemuan 1 fokus pencapaian target hasil belajar kognitif adalah menentukan berat benda. Pada siklus 2 pertemuan 2 fokus peningkatan hasil belajar yaitu mengenai materi membandingkan berat benda. Hasil belajar kognitif peserta didik pada siklus 2 pertemuan 2 juga sudah sangat baik. Dibuktikan dengan hanya satu peserta didik dari 23 peserta didik yang belum mencapai kriteria ketuntasan minimal. Sebanyak $96 \%$ peserta didik sudah mencapai kriteria ketuntasan minimal. Nilai tertinggi dan nilai terendah pada siklus 2 
pertemuan 2 ini adalah 100 dan 60 . Berikut adalah tabel rata-rata skor hasil belajar kognitif pada tiap siklusnya.

Tabel 1. Rata-rata Skor Hasil Belajar Kognitif Secara Klasikal

\begin{tabular}{lcc}
\hline Kegiatan & $\begin{array}{c}\text { Skor Rata-rata } \\
\text { Klasikal }\end{array}$ & Kategori \\
\hline Prasiklus & 56,7 & $\mathrm{BT}$ \\
Siklus 1 Pertemuan 1 & 56,1 & $\mathrm{BT}$ \\
Siklus 1 Pertemuan 2 & 60,0 & $\mathrm{BT}$ \\
Siklus 2 Pertemuan 1 & 75,5 & $\mathrm{~T}$ \\
Siklus 2 Pertemuan 2 & 86,5 & $\mathrm{~T}$
\end{tabular}

Hasil Tindakan pada siklus 1 pertemuan 1 sampai dengan siklus 2 pertemuan 2 sudah menunjukkan peningkatan hasil belajar peserta didik dan keaktifan peserta didik. Peningkatan keaktifan ditunjukkan dengan indikator keaktifan peserta didik yang awalnya mendapat skor rata-rata kurang aktif kemudian meningkat menjadi semakin baik dan bahkan menjadi sangat baik pada akhir pertemuan yang telah dilaksanakan. Keaktifan peserta didik dari kegiatan prasiklus sampai kegiatan siklus 2 pertemuan 2 mengalami peningkatan sebanyak $60,75 \%$ dari kategori kurang aktif menjadi sangat aktif. Sedangkan peningkatan hasil belajar kognitif peserta didik ditunjukkan dengan skor yang diperoleh peserta didik saat mengerjakan soal evaluasi. Hasil belajar kognitif peserta didik pada kegiatan prasiklus yang hanya $23,73 \%$ peserta didik yang tuntas menjadi 95,65\% peserta didik yang tuntas atau mencapai KKM.

Hasil penelitian ini sejalan dengan yang telah dinyatakan oleh Anni (2014: 4), hasil belajar adalah perubahan perilaku yang diperoleh siswa setelah mengalami aktivitas belajar. Penelitian ini juga sejalan dengan pendapat Kristin (2017:223) bahwa hasil belajar adalah merupakan perubahan perilaku siswa setelah mengikuti pelajaran terjadi akibat lingkungan belajar yang sengaja dibuat oleh guru melalui model pembelajaran yang dipilih dan digunakan dalam suatu pembelajaran. Selain itu, penelitian ini juga memperkuat penelitian terdahulu yang telah dilakukan oleh Andika Dinar Pamungkas (2018) dan Rizka Vitasari (2013) bahwa dengan penerapan model problem based learning ( $P B L)$ dapat untuk meningkatkan keaktifan dan hasil belajar peserta didik.

Arends (2012) dalam Ningrum (2016: 217) mengemukakan ada lima sintaks pembelajaran berbasis masalah. Sintaks pembelajaran yang dikemukakan Arends tersebut telah terlaksana dengan baik. Sintaks pertama yaitu orientasi masalah telah terlaksana secara baik dengan dibuktikan melalui penyajian masalah pada setiap proses pembelajaran. Penyajian masalah pada proses pembelajaran disajikan secara berbeda-beda dengan tujuan melatih peserta didik agar mampu berpikir secara kritis. Penyajian masalah dilakukan agar peserta didik secara aktif terlibat dalam proses pemecahan masalah.

\section{SIMPULAN}

Simpulan yang dapat diambil berdasarkan penelitian yang telah dilaksanakan yaitu penerapan model pembelajaran Problem Based Learning (PBL) dapat meningkatkan keaktifan dan hasil belajar kognitif peserta didik kelas IIA SD Negeri 04 Jaten tahun ajaran 2020/2021. Hal tersebut dibuktikan dengan terjadinya peningkatan hasil nilai hasil belajar kognitif dan dibuktikan peningkatan skor pada tiap indikator keaktifan pada setiap pertemuan. Keaktifan peserta didik dari kegiatan prasiklus sampai kegiatan siklus 2 pertemuan 2 mengalami peningkatan sebanyak 60,75 \% dari kategori kurang aktif menjadi sangat aktif. Sedangkan hasil belajar peserta didik pada kegiatan prasiklus yang hanya $23,73 \%$ yang tuntas menjadi $95,65 \%$ yang tuntas atau mencapai KKM. Hasil penelitian memberikan implikasi bagi proses pembelajaran 
berupa peningkatan keaktifan dan hasil belajar kognitif peserta didik melalui penerapan model pembelajaran Problem Based Learning (PBL). Model pembelajaran tersebut efektif dan efisien untuk mengatasi permasalahan sejenis, bahkan model tersebut juga dapat diterapkan dengan baik terhadap permasalahan lain.

\section{DAFTAR PUSTAKA}

Eismawati, dkk. (2019). Peningkatan hasil belajar matematika melalui model pembelajaran problem based learning (PBL) siswa kelas 4 SD. "Jurnal Mercumatika : Jurnal Penelitian Matematika dan Pendidikan Matematika" 3 (2). Diakses tanggal 29 April 2021 (http://ejurnal.mercubuanayogya.ac.id/index.php/mercumatika/article/view/694/510)

Moleong, J Lexy. (2012). Metodologi Penelitian Kualitatif. Bandung: Remaja Rosdakarya.

Ningrum, R. (2016) "Meningkatkan Kemampuan Komunikasi Matematis Siswa Menggunakan Problem Based Learning berbasis Flexible Mathematical Thinking" Jurnal Seminar Nasional Matematika 1 (1). Diakses tanggal 15 Desember 2020, 217 (https://journal.unnes.ac.id/sju/index.php/prisma/article/view/21620/10239)

Nurhidayati, A. (2013). "Peningkatan Hasil Belajar Ranah Afektif Melalui Pembelajaran Model Motivasional" Jurnal IImiah Pendidikan Teknik dan Kejuruan 6 (2). Diakses $\begin{array}{llll}\text { tanggal } & 15 & \text { Desember } & 122\end{array}$ (https://jurnal.uns.ac.id/jptk/article/view/12614/10736).

Oktaviana, D \& Prihatin, I.(2018). "Analisis Hasil Belajar Siswa Pada Materi Perbandingan Berdasarkan Ranah Kognitif Revisi Taksonomi Bloom." Jurnal

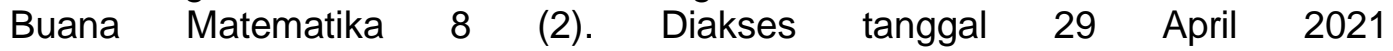
(https://scholar.google.co.id/citations?view_op=view_citation\&hl=id\&user=pPtO5 a0AAAAJ\&citation_for_view=pPtO5a0AAAAJ:hqOjcs7Dif8C).

Pamungkas, A D, dkk. (2018). "Meningkatkan Keaktifan dan Hasil Belajar Siswa Melalui Model Pembelajaran Problem Based Learning (PBL) Pada Siswa Kelas 4 SD" Jurnal Kajian Penelitan Pendidikan dan Pembelajaran 3 (1). Diakses tanggal 15 Desember 2020 (https://core.ac.uk/download/pdf/268138771.pdf).

Putri, A W. (2019). "Alasan Mengapa Kualitas PISA Siswa Indonesia Buruk" Diakses tanggal 29 April 2021 (https://tirto.id/enfy).

Siagian, Muhammad Daut. (2016). "Kemapuan Koneksi Matematik dalam Pembelajaran Matematika." Journal of Mathematics Education and Science 2 (1). Diakses tanggal $\quad 29 \quad$ April 2021 https://jurnal.uisu.ac.id/index.php/mesuisu/article/view/117/94\#: :text=Menurut\% 20para\%20ahli\%20pendidikan\%20matematika,Shadiq\%2C\%202014\%3Axii).

Suchaimiyah \& Latifah. (2016). "Peningkatan Kecerdasan Visual Spasial Anak Usia dini Melalui Melalui Permainan Lego" Jurnal PG PAUD Trunojoyo. Diakses tanggal $29 \quad$ April 2021 (https://journal.trunojoyo.ac.id/pgpaudtrunojoyo/article/download/3479/\%28INDO NESIAN\%29).

Vitasari, Rizka, dkk. 2013. "Peningkatan Keaktifan dan Hasil Belajar Matematika Melalui Model Problem Based Learning Siswa Kelas V SD Negeri 5 Kutosari" Jurnal Kalam Cendekia PGSD Kebumen 5 (3). Diakses tanggal 15 Desember 2020 (https://scholar.google.co.id/citations?user=kiRqSWAAAAAJ\&hl=id). 